\title{
Analysis of In Situ Protease Activity in Chronic Adult Periodontitis Patients: Expression of Activated MMP-2 and a 40 kDa Serine Protease
}

Jonathan M. Korostoff, * Jian Fei Wang, ${ }^{\dagger}$ David P. Sarment, ${ }^{\ddagger}$ Jeffrey C.B. Stewart, $§^{\S}$ Roy S. Feldman, ${ }^{\ddagger}$ and Paul C. Billings

Background: Periodontitis is characterized by extensive destruction of the gingival tissues and associated supporting structures of the teeth. Although the pathogenesis of the various forms of this disease is not completely understood, host-derived proteases are believed to have an important role. In this study, we analyzed human tissue samples from chronic adult periodontitis patients to assess the levels of specific proteases and determine the effect of $\mathrm{pH}$ and tetracyclines on their activity.

Methods: Gingival tissue samples were obtained from patients with chronic adult periodontitis (probing depths ranged from 5 to $9 \mathrm{~mm}$ ) and periodontally healthy controls. Tissue extracts were prepared and analyzed for protease activity by zymography and Western blotting.

Results: Maximal protease activity from clinically normal and diseased tissues was observed at $\mathrm{pH}$ 8. Latent matrix metalloproteinase (MMP)- 9 and MMP- 2 were expressed in all samples examined, while active MMP-2 was detected only in tissues obtained from patients with clinical disease. The MMP activities were differentially inhibited by derivatives of tetracycline. At $\mathrm{pH} 6$, a protease with a mass of approximately $40 \mathrm{kDa}$ was observed in diseased samples. The enzymatic activity was inhibited by phenylmethylsulfonyl fluoride, suggesting it is a serine protease.

Conclusions: The results of the current study substantiate the proposed role of host-derived proteases in the pathogenesis of chronic adult periodontitis. Specifically, they indicate that activated MMP-2 and a $40 \mathrm{kDa}$ serine protease are involved in tissue destruction associated with this form of periodontal disease and also suggest that tissue $\mathrm{pH}$ influences protease activity in situ. $J$ Periodontol 2000;71:353-360.

\section{KEY WORDS}

Periodontitis/pathogenesis; proteases, matrix metallo; proteases, serine; periodontitis/drug therapy; tetracycline/therapeutic use.

\footnotetext{
* Department of Microbiology, School of Dental Medicine, University of Pennsylvania, Philadelphia, PA.

$\dagger$ Currently, Animal Resources Center, University of Calgary, Calgary, Alberta, Canada; previously, Department of Pathology, School of Dental Medicine, University of Pennsylvania.

* Currently, Department of Periodontics/Prevention/Geriatrics, University of Michigan Dental

School, Ann Arbor, MI; previously, Department of Periodontics, School of Dental Medicine,

University of Pennsylvania.

§ Currently, Department of Pathology, Oregon Health Sciences University, Portland, OR; previously,

Department of Pathology, School of Dental Medicine, University of Pennsylvania, Philadelphia, PA.

\| Dental Service, Veterans Affairs Medical Center, Philadelphia, PA.

II Department of Histology and Anatomy, School of Dental Medicine, University of Pennsylvania.
}

$\mathrm{t}$ is widely believed that destruction of the connective tissue attachment of teeth and adjacent alveolar bone observed in patients with chronic adult periodontitis is a consequence of host inflammatory reactions initiated in response to bacterial colonization of the subgingival environment. ${ }^{1} \mathrm{~A}$ variety of factors contribute to the pathogenesis of periodontitis including inadequate oral hygiene, dietary and genetic components, as well as composition of the oral microbiota. ${ }^{2}$ While the specific precipitating factors are not completely understood, the initial response by the host involves activation and mobilization of inflammatory cells such as macrophages, lymphocytes, and neutrophils. ${ }^{3}$ Among the consequences of these events are altered levels of specific immunomodulators and the release of inflammatory proteases. ${ }^{3,4}$ Many proteases are capable of degrading a wide variety of substrates including collagen, a major constituent of the extracellular matrix (ECM) within the periodontium. The enhanced activity of these enzymes is thought to be involved in the extensive tissue destruction observed in many chronic inflammatory diseases.

A number of studies have implicated matrix metalloproteinases (MMPs) and other proteases as playing a central 
role in the pathogenesis of periodontal disease (reviewed in reference 5). As a group, the MMPs are capable of degrading the majority of proteins found within the ECM. Several reports have documented the presence of specific MMPs including gelatinases A and B (MMP2 and MMP-9), interstitial collagenases (MMP-1 and MMP-8), and stromelysin (MMP-3) in gingival biopsy specimens and gingival crevicular fluid (GCF). 5-7 Makela et al. detected increased levels of MMP-2 and MMP-9 in periodontitis patients and found that latent MMP-9 (92 kDa) was the major gelatinase in GCF and saliva. ${ }^{8}$ Recent studies utilizing a quantitative reverse transcriptase-polymerase chain reaction (RT-PCR) have shown preferential expression of MMP-3, followed by MMP- 1 and MMP- 8 in periodontitis-affected tissue. ${ }^{9}$ Lee and colleagues demonstrated an association between increased GCF MMP- 8 activity and progressive loss of connective tissue attachment, ${ }^{10}$ while longitudinal studies have shown a significant decrease in GCF MMP activity following successful periodontal treatment. ${ }^{11,12}$ In addition, increases in the levels of neutrophil-derived serine proteases, such as cathepsin $G$ and thiol proteases, have also been associated with periodontal tissue breakdown. ${ }^{13,14}$ Taken together, these results strongly suggest that host-derived proteases play an important role in tissue destruction observed in periodontal disease.

In situ, protease activity is controlled at multiple levels. These include: 1) transcriptional regulation of the genes encoding individual enzymes; 2) sequestration of proteolytic enzymes in intracellular vesicles; 3) regulation of processing and activation of latent proenzymes; 4) presence of endogenous inhibitors including the tissue inhibitors of metalloproteinases (TIMPs) and serine protease inhibitors (serpins); and 5) effects of specific local environmental factors such as tissue $\mathrm{pH}$. With respect to chronic inflammatory diseases in general, compounds that inhibit proteolytic degradation of the ECM have potential therapeutic value. It is well established that tetracycline (TC) and its derivatives inhibit collagenases (MMP-1 and -8) via a mechanism independent of their antimicrobial activity (reviewed in reference 15). In clinical trials, adult periodontitis patients treated with low-dose regimens of doxycycline exhibited reduced levels of gingival and GCF collagenase activity in association with decreased attachment loss relative to controls. ${ }^{16-18}$ The efficacy of this treatment was attributed to collagenase inhibition. The effect of doxycycline and other TCs on the gelatinases (MMP-2 and -9) is less well defined.

In the current report, we used gelatin zymography and Western blot analysis to systematically assess protease activity in gingival biopsy samples. Specifically, the objectives of this study were to: 1) determine whether the levels of activated MMP- 2 and MMP-9 dif- fered in diseased versus healthy tissue; 2) assess the effect of $\mathrm{pH}$ on protease activity; and 3) evaluate the effect of tetracyclines on in situ protease activity.

\section{MATERIALS AND METHODS}

\section{Chemicals}

ADA (N-[2-acetamido]-2-iminodiacetic acid), BBI (Bowman-Birk inhibitor), CAPS (3-[cyclohexylamino]l-propanesulfonic acid), DFP (diisopropylfluorophosphate), TRIS (Tris[hydroxymethyl]aminomethane]), 1,10-phenanthroline and gelatin were obtained from Sigma Chemical Company (St. Louis, Missouri). Rabbit anti-MMP-2 (gelatinase A) polyclonal antibodies were obtained from Chemicon (Temecula, California), and rabbit anti-MMP-9 (gelatinase B) polyclonal antibodies were generously provided by Dr. Joel Rosenbloom (University of Pennsylvania).

\section{Tissue Samples}

Gingival tissue samples were obtained from three sources: 1) the Graduate Periodontics Clinic, University of Pennsylvania School of Dental Medicine; 2) the Department of Oral and Maxillofacial Surgery and Hospital Dentistry, Hospital of the University of Pennsylvania; and 3) Dental Clinic, Veterans Administration Hospital, Philadelphia, Pennsylvania. All subjects underwent scaling and root planing in 4 quadrants prior to periodontal surgery. Patients scheduled to have gingival tissue removed during pocket elimination surgery for treatment of chronic adult periodontitis (probing depths 5 to $9 \mathrm{~mm}$ ) served as the source of diseased tissues. These patients exhibited mild gingival inflammation and erythema with localized bleeding on probing. None of the sites in the surgical areas was suppurating. Healthy, clinically non-inflamed tissues were obtained from a group of patients without periodontal disease, who were undergoing crown lengthening or soft tissue grafting procedures. Each subject provided a single tissue sample. The sample cohort consisted of 8 clinically healthy and 32 diseased samples from a total of 40 subjects. The study was approved by the Institutional Review Board of the University of Pennsylvania. Informed consent was obtained from each patient at the time of periodontal surgery.

Following surgery, excised tissue specimens were immediately placed on ice and subsequently frozen $\left(-80^{\circ} \mathrm{C}\right)$. To prepare tissue extracts, samples were thawed on ice, homogenized in PBS, and centrifuged $\left(10,000 \mathrm{~g} \times 10\right.$ minutes, $\left.4^{\circ} \mathrm{C}\right)$. Protein concentration in the extracts ranged from 2 to $15 \mathrm{mg} / \mathrm{ml}$ as determined by a reagent" using bovine serum albumin (BSA) as standard. For storage, the supernatants were diluted with an equal volume of glycerol and stored at $-20^{\circ} \mathrm{C}$. We have found that most proteases are stable for several months under these conditions.

\# BCA Protein Assay Reagent, Pierce, Rockford, IL. 


\section{Protease Assays}

Protease activity was assessed on gelatin zymograms. Twelve percent $(12 \%)$ polyacrylamide gels $(0.75 \mathrm{~mm}$ thickness) were cast ${ }^{19}$ containing $0.15 \%$ gelatin as substrate. ${ }^{20,21}$ Samples were applied to the gels under non-reducing conditions without heating. The gels were run, soaked in $200 \mathrm{ml}$ of $2 \%$ Triton X-100 in distilled water on a gyratory shaker $\left(0.5\right.$ hours, $\left.20^{\circ} \mathrm{C}\right)$, and incubated in developing buffer ( $50 \mathrm{mM}$ Tris [pH 8.0], $1 \mathrm{mM} \mathrm{CaCl} 2$ ), unless otherwise indicated, for 15 hours at $37^{\circ} \mathrm{C}$. For visualization, the gels were stained with Coomassie blue. Protease activity shows up as clear bands (indicative of cleavage of the gelatin substrate) on a blue background.

For inhibition studies, zymograms were incubated in reaction buffer containing specific protease inhibitors: DFP ( $1 \mathrm{mM})$, EDTA $(5 \mathrm{mM})$, BBI $(10 \mu \mathrm{g} / \mathrm{ml})$, phenylmethyl sulfonyl fluoride (PMFS) $(50 \mu \mathrm{M})$ or tetracyclines $(0.1$ and $0.25 \mathrm{mM})$. To determine protease activity as a function of $\mathrm{pH}$, samples were run on zymograms and subsequently incubated in the appropriate buffer ( $50 \mathrm{mM}$ citrate-phosphate buffer [pH 5], $50 \mathrm{mM}$ ADA buffer [pH 6 and 7], $50 \mathrm{mM}$ TRIS [pH 8 and 9] or $50 \mathrm{mM}$ CAPS [pH 10]), containing $1 \mathrm{mM} \mathrm{CaCl}$. All zymograms presented are representative results obtained in the course of these studies.

\section{Western Immunoblots}

Tissue extracts were run on SDS-polyacrylamide gels and transferred to nitrocellulose membranes. The membranes were subsequently blocked in tris-buffered saline (TBS) (50 mM Tris [pH 7.5], $150 \mathrm{mM} \mathrm{NaCl})$ containing $5 \%$ powdered milk and $1 \%$ BSA for 30 minutes, and then incubated with polyclonal anti-MMP-2 or anti-MMP-9 antibodies (prepared in rabbits) (diluted $1: 1,000$ in TBS $/ 1 \%$ BSA) for 2 hours at $37^{\circ} \mathrm{C} .{ }^{22}$ The use of the anti-MMP-9 antibody has been described previously. ${ }^{23}$ The membrane was washed and incubated with a horseradish peroxidase (HRP)-conjugated goat anti-rabbit secondary antibody (diluted $1: 10,000$ in TBS containing $20 \mu \mathrm{l}$ normal goat serum $/ \mathrm{ml}$ ) for $30 \mathrm{~min}$ utes at room temperature. Bound antibody was detected by chemiluminescence using a substrate system. ${ }^{* *}$

\section{RESULTS}

The goal of this study was to investigate protease activity in human gingival tissue using gelatin zymography and Western blotting analysis. In order to evaluate assay sensitivity, defined amounts of trypsin were run on a zymogram containing gelatin as substrate. Using this approach, $1 \mathrm{ng}$ of trypsin was readily detected; gelatin cleavage was directly proportional to the amount of protease loaded (Fig. 1). This observation enabled us to estimate the relative amounts of protease activity in gingival tissue and to compare the levels of enzymatic activity in healthy versus diseased

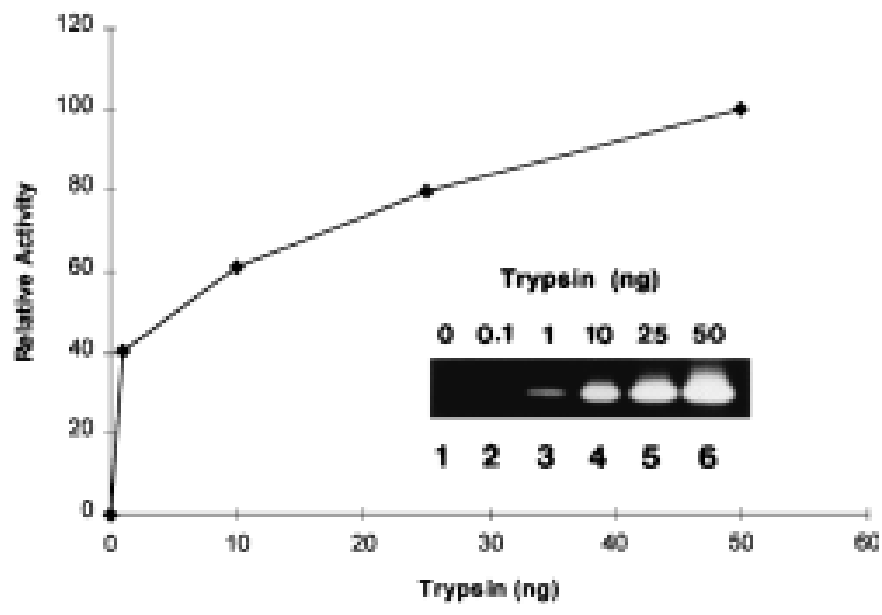

Figure 1 .

Zymogram sensitivity. Increasing amounts of trypsin were run on a I $2 \%$ polyacrylamide gel containing gelatin as substrate. The gel was incubated in $50 \mathrm{mM}$ Tris ( $\mathrm{pH} 8.0), 1 \mathrm{mM} \mathrm{CaCl} 2\left(4\right.$ hours, $\left.37^{\circ} \mathrm{C}\right)$ and stained with Coomassie blue. The amount of gelatin cleavage (clear areas on the gel), indicative of protease activity, was determined by densitometry. Enzymatic activity was determined as the relative protease activity compared to that observed with $50 \mathrm{ng}$ of trypsin (equivalent to 100 arbitrary units). Inset: Gelatin zymogram; lanes I through 6 contain 0 to $50 \mathrm{ng}$ of trypsin. Note that I ng of trypsin is readily detectable in this system.

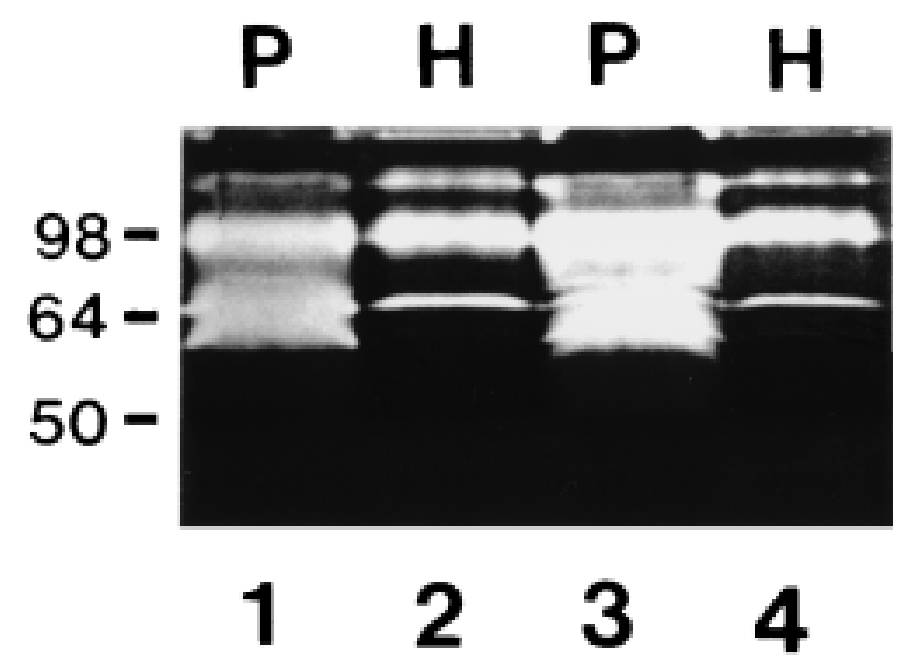

Figure 2.

Protease activity in periodontal tissue. Extracts were prepared from gingival tissue and analyzed on gelatin zymograms. The zymogram was developed at pH 8 and stained. Lanes I through 4 contained $30 \mu \mathrm{g}$ protein from each sample ( $P$, tissue obtained from periodontitis patients; H, healthy tissue). The numbers on the left indicate molecular mass in kDa. Note that diseased tissues have higher levels of protease activity compared with healthy tissue.

\footnotetext{
* * SuperSignal CL-HRP, Pierce.
} 
specimens. For analysis, equivalent amounts of protein from each sample were run on zymograms and incubated in developing buffer (50 $\mathrm{mM}$ Tris [pH 8], 1 $\mathrm{mM} \mathrm{CaCl} 2$ ). Under these conditions, both the latent and active forms of MMPs are detected. Elevated levels of protease activity with masses of approximately 60 to $90 \mathrm{kDa}$ were consistently observed in samples from patients with periodontal disease (Fig. 2). In the course of these studies, we found the pattern of protease activity present in a particular sample to be highly reproducible.

For initial characterization, we evaluated the ability of proteases present in our samples to bind gelatin. Tissue extracts were incubated with gelatin-sepharose, the resin was washed, and bound proteins were eluted and analyzed on gelatin zymograms. Proteases of approximately 92,72 , and $64 \mathrm{kDa}$ bound gelatin (Fig. 3). The sizes of these proteins are consistent with those of latent MMP-9 and latent and active MMP-2, respectively. Further, MMP-2 and MMP-9 have a fibronectin-like domain that enables them to bind gelatin, ${ }^{24}$ indicating that proteins present in gingival samples share characteristics with these proteases.

Protease identity was confirmed on Western blots. Antibodies to MMP- 2 cross-reacted with a $72 \mathrm{kDa}$ protein present in all tissue samples, indicating that the latent form of MMP-2 is expressed in normal and inflamed gingival tissue (Fig. 4). Several diseased samples also expressed a $64 \mathrm{kDa}$ protein that crossreacted with anti-MMP-2 antibodies. Since latent MMP2 loses a nearly $10 \mathrm{kDa}$ fragment from the $\mathrm{N}$-terminus upon activation, 24,25 the size of this protein is consistent with the presence of active MMP-2 in inflamed tissue. Additionally, anti-MMP-9 antibodies cross-reacted with proteins in all samples examined (data not shown). However, only the latent (92 kDa) form of this enzyme was present in normal and diseased tissue specimens.

In the next series of experiments, we determined the effect of specific protease inhibitors on gelatin cleavage. For these studies, zymograms were run and subsequently incubated in developing buffer in the absence or presence of specific protease inhibitors. When incubated in the presence of EDTA (Fig. 5) or 1,10-phenanthroline (data not shown), the 92, 72, and $64 \mathrm{kDa}$ proteases present in diseased tissue samples were inhibited, confirming that they are metalloproteinases. The sizes of these enzymes correspond to those of latent MMP-9 (92 kDa) and latent and active forms of MMP-2 (72 and $64 \mathrm{kDa}$, respectively), supporting the results obtained on Western blots. However, a protease of nearly 75 $\mathrm{kDa}$ was not affected by metal chelators (Fig. 5) and was consistently present at higher levels in inflamed

Figure 4.

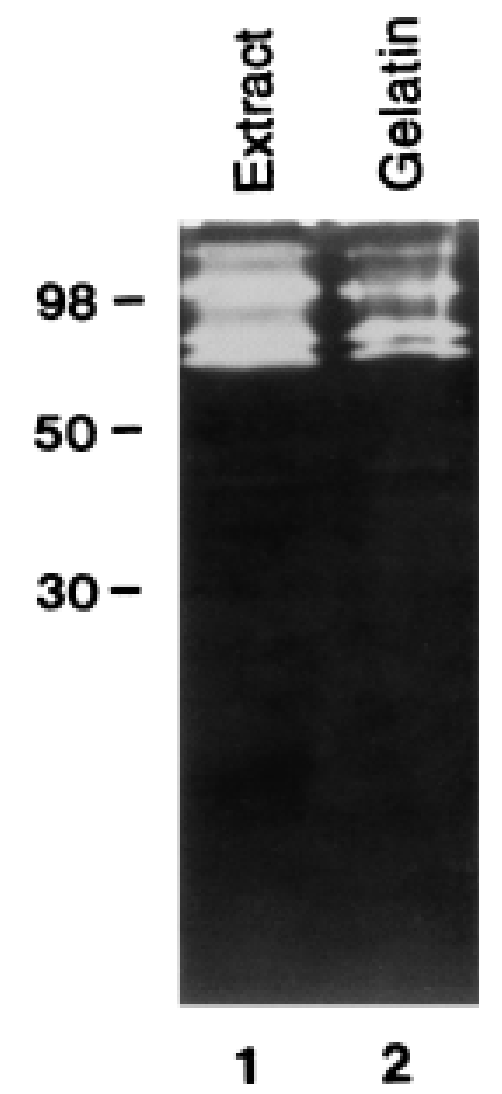

Figure 3.

Gelatin binding of protease activity. An extract prepared from inflamed gingiva was incubated with gelatin-sepharose, the resin was washed, and bound proteins were eluted with SDS-gel loading buffer and run on a gelatin zymogram. Lane I, input extract; lane 2, proteases binding to gelatin-sepharose. Note that proteases of $\sim 92,72$, and $64 \mathrm{kDa}$ bind to immobilized gelatin. Numbers on the left represent molecular mass in $k D a$. versus healthy tissue. This activity was completely inhibited when the zymograms were incubated with EDTA and DFP (a potent inhibitor of serine pro-

Western analysis of samples for MMP-2. Cell extracts (50 $\mu \mathrm{g}$ protein/lane) were run on SDS-polyacrylamide gels and transferred to nitrocellulose membranes. The membranes were incubated with antibodies to MMP-2. For some samples, extracts were incubated with gelatin sepharose; bound proteins were extracted and run on the gel (lanes 8 through 10). Lanes designated D and $H$ represent extracts prepared from diseased and healthy tissue, respectively. Note the presence of latent (arrow on right) and active MMP-2 in diseased tissue samples. Numbers on the left indicate molecular mass in $\mathrm{kDa}$. 


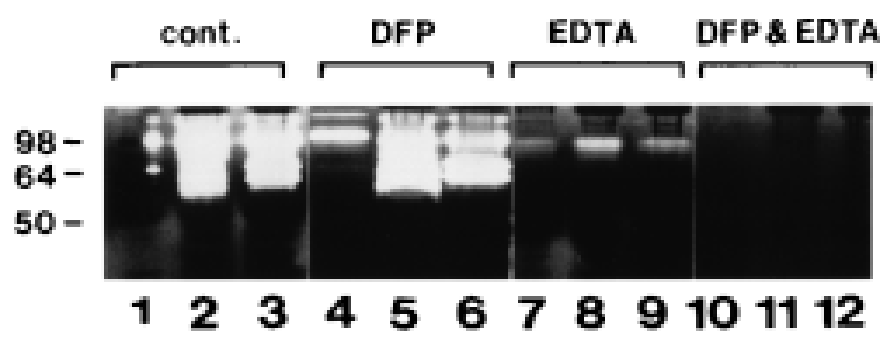

Figure 5.

Effect of inhibitors on protease activity. Tissue extracts were run on gelatin zymograms. The zymograms were incubated in developing buffer ( $p H$ 8) containing no inhibitor (lanes I through 3), DFP (serine protease inhibitor, lanes 4 through 6), EDTA (an inhibitor of metalloproteinases, lanes 7 through 9) or DFP and EDTA (lanes 10 through 12). Lanes I, 4, 7, and 10 contain extracts of healthy tissue; remaining lanes contain diseased tissue extracts. Numbers on the left indicate molecular mass in $\mathrm{kDa}$.

teases $^{26}$ ) or EDTA and BBI (an $8 \mathrm{kDa}$ soybean-derived inhibitor of trypsin and chymotrypsin; ${ }^{27}$ data not shown). In contrast, $\mathrm{N}$-ethylmaleimide (NEM) and pepstatin, inhibitors of thiol and acid proteases, respectively, had no effect on enzyme activity associated with the $75 \mathrm{kDa}$ protein. These results demonstrate that the EDTA-resistant bands are serine proteases.

Tetracycline and its derivatives have been shown to inhibit collagenase activity and prevent periodontal attachment loss when administered at low doses. ${ }^{15-18,28}$ Experiments were performed to assess the effect of these compounds on protease activity present in our tissue samples. Tissue extracts were run on zymograms and subsequently incubated in developing buffer containing tetracycline, doxycycline, or minocycline. Each antibiotic was tested at concentrations of 0.1 and $0.25 \mathrm{mM} .{ }^{29}$ All three compounds inhibited gelatin cleavage by MMP-2 and MMP-9 (Fig. 6). Doxycycline and minocycline were more effective at inhibiting the activity of these proteases when compared to tetracycline.

To assess the effect of $\mathrm{pH}$ on protease activity, gingival extracts were run on zymograms and subsequently incubated in buffers of increasing $\mathrm{pH}$ (6 to 10). Maximal cleavage of gelatin, indicative of protease activity, was observed at pH 8 (Fig. 7). Interestingly, a protease activity (molecular mass $40 \mathrm{kDa}$ ) was present when the zymograms were incubated under more acidic conditions ( $\mathrm{pH}$ 6, Fig. 7). This protease was expressed in the majority of diseased gingival tissue (90\%) but was not detected in healthy tissue extracts (0/8 samples). This protease was inhibited by PMSF, but not by EDTA, NEM, or pepstatin (Fig. 8), suggesting that the $40 \mathrm{kDa}$ enzyme is a serine protease.

\section{DISCUSSION}

In this study, we demonstrate increased protease activity in diseased gingival tissue. Several lines of evi-

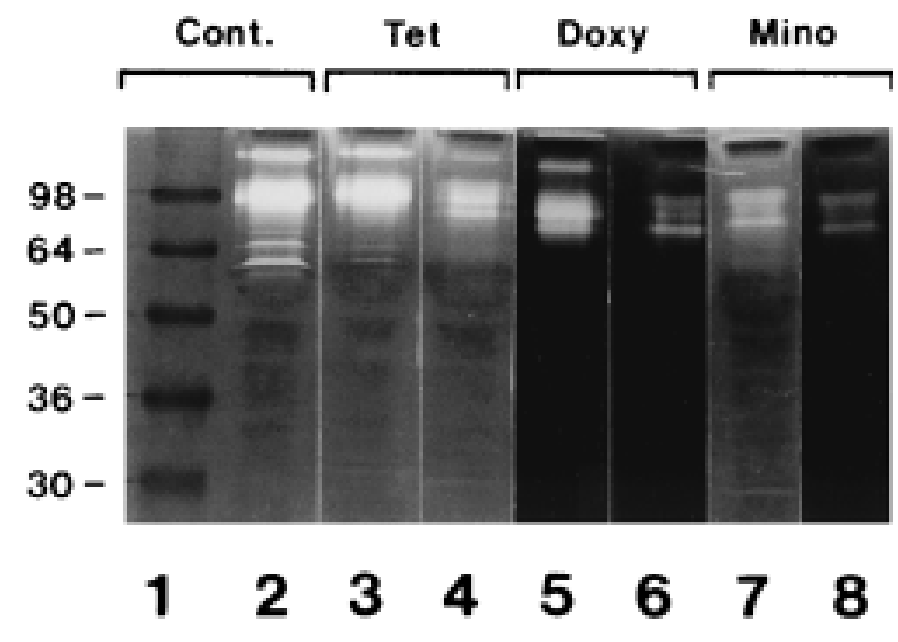

Figure 6.

Effect of tetracyclines on protease activity. Inflamed tissue extracts were run on gelatin zymograms. After electrophoresis, the zymograms were incubated in reaction buffer $(\mathrm{pH} 8)$ in the absence (lanes 1 and 2) or presence of 0.1 or $0.25 \mathrm{mM}$ tetracycline (lanes 3 and 4 , respectively), 0.1 or $0.25 \mathrm{mM}$ doxycycline (lanes 5 and 6, respectively), or 0.1 or $0.25 \mathrm{mM}$ minocycline (lanes 7 and 8 , respectively). Note that relative to tetracycline, both doxycycline and minocycline are more efficient at inhibiting protease activity. Numbers on the left indicate molecular mass in $\mathrm{kDa}$.

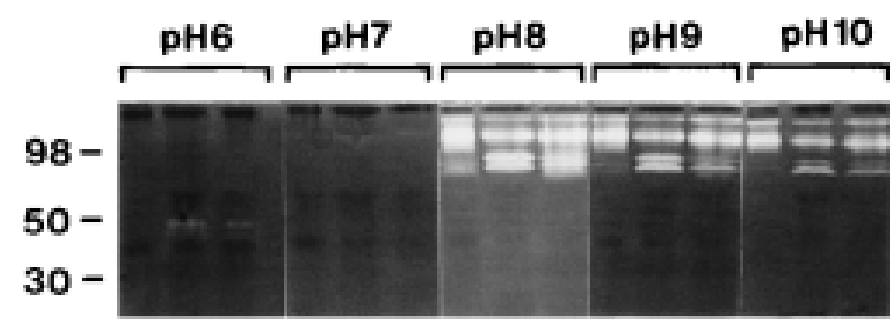

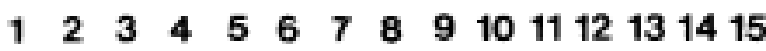

\section{Figure 7.}

Protease activity as a function of $\mathrm{pH}$. Tissue extracts were run on a gelatin zymogram and incubated at $37^{\circ} \mathrm{C}$ in buffers of: $\mathrm{pH} 6$ (lanes 1 through 3), pH 7 (lanes 4 through 6), pH 8 (lanes 7 through 9), pH 9 (lanes 10 through / 2), and pH 10 (lanes 13 through 15). Lanes I, 4, 7 , 10 , and 13 show extracts prepared from healthy tissues, while the remaining lanes contain diseased tissue extracts. Note the presence of a $40 \mathrm{kDa}$ protease at $\mathrm{pH} 6$ in lanes 2 and 3 (containing extracts prepared from diseased tissues). Numbers on the left indicate molecular mass in $\mathrm{kDa}$.

dence indicate that two of these proteases are MMP2 and MMP-9: 1) the sizes of these proteases on the zymograms were consistent with their known masses; 2) they efficiently degraded gelatin and bound to gelatin agarose; 3 ) their activity was inhibited by EDTA and 1,10-phenanthroline; and 4) they reacted with anti-MMP-2 and anti-MMP-9 antibodies on Western blots.

MMPs are secreted as latent (inactive) enzymes and, upon conversion into their active forms, lose a 


\section{pH6}

\section{pH8 Cont. EDTA PMSF}

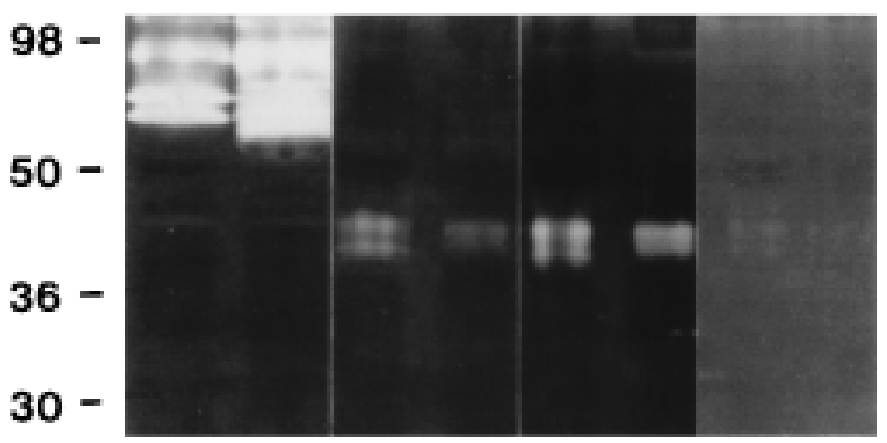

Figure 8.

Effects of inhibitors on $40 \mathrm{kDa}$ protease activity. Inflamed tissue extracts from two periodontitis patients were run on gelatin zymograms. After electrophoresis, the zymograms were incubated in reaction buffer at $\mathrm{pH} 8$ without inhibitors or at $\mathrm{pH} 6$ in the absence or presence of $5 \mathrm{mM}$ EDTA or I mM PMSF. Note that the $40 \mathrm{kDA}$ protease is active at $\mathrm{pH} 6$ and is inhibited by PMSF but not by EDTA. Numbers on the left indicate molecular mass in kDa.

$10 \mathrm{kDa}$ fragment from the $\mathrm{N}$-terminal region of the protein. ${ }^{24,25}$ Latent forms of MMP-2 and MMP-9 were detected in all tissue samples on gelatin zymograms and Western blots. We consistently observed higher levels of latent MMP-2 and MMP-9 in diseased tissues. While it has been reported previously that increased levels of MMP-2 and MMP-9 are observed in periodontitis patients and that latent MMP-9 (92 kDa) is the major gelatinase activity in oral GCF and saliva, $5,7-9,11,12$ the presence of the active forms of these proteases has not been extensively examined. In the current investigation, we consistently observed a protease of $\sim 64 \mathrm{kDa}$ on the gelatin zymograms in all diseased tissue samples (Figs. 2 and 3). This protein also cross-reacted with anti-MMP-2 antibodies, strongly indicating it is the activated form of MMP2. We believe this is the first report showing activated MMP-2 in diseased periodontal tissue. Our results are in contrast to those of Sorsa et al. ${ }^{29}$ who reported little immunoreactivity with antibodies to MMP-2 in inflamed gingival tissues. This could be a reflection of differences in the clinical status of the patients studied. Alternatively, the use of a commercially available MMP-2-specific antibody may have afforded us greater sensitivity on our Western blots. Finally, it is possible that our results were due to protease activation that ocurred during in vitro tissue processing. However, two points argue against this. First, we found no evidence of MMP-9 activation in diseased tissues. If activation were an artifact of tissue handling, we would expect to have detected other activated MMPs as well. Second, we did not observe changes in MMP-2 status when the same tissue was analyzed at different times. We therefore consider our results to be an accurate reflection of MMP status in situ. Since MMP-2 is derived from fibroblasts and macrophages, our data suggest that metalloproteinases of non-neutrophil origin are also involved in tissue destruction during the progression of periodontitis.

Tetracycline derivatives are currently being utilized to treat patients with advanced periodontal disease. ${ }^{28}$ In addition to their bacteriostatic effects, these compounds have been shown to inhibit collagenase activity. ${ }^{15,16}$ However, their effect on MMP-2 and MMP-9 in human gingival tissue has not been fully evaluated. In this study we found that tetracycline, doxycycline, and minocycline inhibited MMP-2 and MMP-9. These compounds are thought to inhibit MMP activity by chelating metal ions; they may also block conversion of latent proteases into their mature active forms. ${ }^{11,28}$ Complete inhibition of MMP-2 was observed with $100 \mu \mathrm{M}$ doxycycline and minocycline. These results indicate that the clinical efficacy of tetracycline derivatives may be due in part to their ability to block the conversion of latent MMP-2 into its active form and directly inhibit its proteolytic activity.

In addition to elevated metalloproteinase activity in inflamed tissue, other protease activities were also increased. These included a $75 \mathrm{kDa}$ protease which is sensitive to DFP and $\mathrm{BBI}$, indicating that it is a serine protease. Interestingly, when the zymograms were incubated at $\mathrm{pH} 6$, a protease of approximately $40 \mathrm{kDa}$ was observed. Expression of this activity was restricted to diseased gingival tissues. To our knowledge, detection of proteases with these properties has not been reported in inflamed periodontal tissues. Based on their size, both the 40 and $75 \mathrm{kDa}$ enzymes appear to be distinct from elastase $(\sim 30 \mathrm{kDa})$ and cathepsin $\mathrm{G}(\sim 30$ $\mathrm{kDa})$, two neutrophil-derived serine proteases. ${ }^{30}$

We also observed a pronounced effect of $\mathrm{pH}$ on overall protease activity (Fig. 7). Not surprisingly, MMPs were clearly active at neutral and alkaline $\mathrm{pH}$ but not at acidic $\mathrm{pH}$. However, we did observe a low molecular weight activity at $\mathrm{pH} 6$ that was inhibited by PMSF, suggesting that this enzyme is a serine protease. This activity was detected only in extracts prepared from inflamed tissues. It is tempting to speculate that in vivo protease activity will be influenced by local differences in $\mathrm{pH}$ and, further, that $\mathrm{pH}$ may have a major effect on the distribution of active proteases in intact tissue. For example, tissue $\mathrm{pH}$ will likely vary depending upon metabolic and redox state, degree of inflammation, blood flow, and other factors. ${ }^{31,32}$ The results of our analysis suggest that MMP activity will be highest under conditions where tissue $\mathrm{pH}$ is neutral or alkaline, while other proteases would be 
expected to be active at more acidic $\mathrm{pH}$, which could potentially develop under inflammatory conditions. The $40 \mathrm{kDa}$ protease described in this report (Fig. 8) may be active in such areas.

The results obtained in the current study support the thesis that host-derived proteases are directly involved in the tissue destruction observed in periodontitis. Specifically, we have observed increased levels of active MMP-2 and a unique $40 \mathrm{kDa}$ protease in tissue samples derived from chronic periodontitis patients. Our observations suggest that these enzymes may play a more important role in the pathogenesis of periodontal disease than previously thought. Current clinical research indicates that protease inhibitors may have significant potential as adjuncts for treating a variety of intraoral diseases including periodontal disease $^{11,29}$ and oral cancer. ${ }^{30,33}$ Future studies will be directed at: 1) purification and characterization of the $40 \mathrm{kDa}$ serine protease and 2) identification of compounds that selectively inhibit MMP-2 and the serine protease to evaluate their efficacy in the treatment of periodontal disease.

\section{ACKNOWLEDGMENTS}

We thank Drs. Edward Lally, Norton Taichman, and Max Listgarten for helpful suggestions. We also thank Ms. Beatrice Engelsberg for technical assistance.

\section{REFERENCES}

1. Listgarten MA. Nature of periodontal diseases: Pathogenic mechanisms. J Periodont Res 1987;22:172-178.

2. Smalley JW. Pathogenic mechanisms in periodontal disease. Adv Dent Res 1994;8:320-328.

3. Mitchell RN, Cotran RS. Acute and chronic inflammation. In: Cotran RS, Kumar V, Robbins SL, Schoen FJ, eds. Basic Pathology, 6th ed. Philadelphia: W.B. Saunders; 1994:51-92.

4. Birkedal-Hansen $\mathrm{H}$. Role of cytokines and inflammatory mediators in tissue destruction. J Periodont Res 1993; 28:500-510.

5. Birkedal-Hansen H, Moore WGI, Bodden MK, et al. Matrix metalloproteinases: A review. Crit Rev Oral Biol Med 1993;4:197-250.

6. Reynolds JJ. Collagenases and tissue inhibitors of metalloproteinases: A functional balance in tissue degradation. Oral Dis 1996;2:70-76.

7. Westerlund $U$, Ingman T, Lukinmaa PL, et al. Human neutrophil gelatinase and associated lipocalin in adult and localized juvenile periodontitis. J Dent Res 1996; 75:1553-1563.

8. Makela M, Uitto V-J, Larjava H. Matrix metalloproteinases (MMP-2 and MMP-9) of the oral cavity: Cellular origin and relationship to periodontal status. J Dent Res 1994; 73:1397-1406.

9. Kubota T, Nomura T, Takahashi T, Hara K. Expression of mRNA for matrix metalloproteinases and tissue inhibitors of metalloproteinases in periodontitis-affected human gingival tissue. Arch Oral Biol 1996;41:253262.

10. Lee W, Aitken S, Sodek J, McCulloch C. Evidence of a direct relationship between neutrophil collagenase activity and periodontal tissue destruction in vivo: Role of active enzymes in periodontitis. J Periodont Res 1995; 30:23-33.

11. Ryan ME, Ramamurthy NS, Golub LM. Matrix metalloproteinases and their inhibition in periodontal disease. Curr Opin Periodontol 1996;3:85-96.

12. Haerian A, Adonogianaki E, Mooney J, Docherty JP, Kinane DF. Gingival crevicular stromelysin, collagenase and tissue inhibitor of metalloproteinase levels in healthy and diseased sites. J Clin Periodontol 1995; 22:505-509.

13. Lah TT, Babnik J, Schiffmann E, Turk V, Skaleric U. Cysteine proteinases and inhibitors in inflammation: Their role in periodontal disease. J Periodontol 1993;64:485491.

14. Kunimatsu K, Mine N, Kato 1, Hase T, Aoki Y, Yamamoto K. Possible functions of human neutrophil serine proteinases medullassin and cathepsin G in periodontal tissue breakdown. J Periodont Res 1993;28:547-549.

15. Golub LM, Ramamurthy NS, McNamara TF. Tetracyclines inhibit connective tissue breakdown: New therapeutic implications for an old family of drugs. Crit Rev Oral Biol Med 1991;2:297-322.

16. Golub LM, Ciancio S, Ramamurthy NS, Leung M, McNamara TF. Low-dose doxycycline therapy: Effect on gingival and crevicular fluid collagenase activity in humans. J Periodont Res 1990;25:321-330.

17. Bouwsma O, Payonk G, Baron H, Sipos T. Low-dose doxycycline: Effects on clinical parameters in adult periodontitis. J Dent Res 1992;71(Spec. Issue):245(Abstr. 1119).

18. Schroeder KL, Ramamurthy NS, Szckepanek KA, et al. Low-dose doxycycline (LDD) prevents attachment loss in adult periodontitis. J Dent Res 1992;71(Spec. Issue): 758(Abstr. 1936).

19. Laemmli UK. Cleavage of structural proteins during the assembly of bacteriophage T4. Nature 1970;227:680685.

20. Billings PC, Habres JM, Liao DC, Tuttle SW. A protease activity in human fibroblasts which is inhibited by the anticarcinogenic Bowman-Birk protease inhibitor. Cancer Res 1991;50:5539-5543.

21. Heussen C, Dowdle EB. Electrophoretic analysis of plasminogen activators in polyacrylamide gels containing sodium dodecyl sulfate and copolymerized substrates. Anal Biochem 1980;102:196-202.

22. Harlow E, Lane D. Antibodies: A Laboratory Manual. New York:Cold Spring Harbor Laboratory;1988:471510.

23. Zhou H, Bernhard EJ, Fox FE, Billings PC. Induction of metalloprotease activity in human $\mathrm{T}$ lymphocytes. Biochim Biophys Acta 1993;1177:174-178.

24. Murphy G, Docherty AJP. The matrix metalloproteinases and their inhibitors. Am J Respir Cell Mol Biol 1992; 7:120-125.

25. Woessner JF. Matrix metalloproteinases and their inhibitors in connective tissue remodeling. FASEB $J$ 1991;5:2145-2154.

26. Shaw E. Site-specific reagents for chymotrypsin, trypsin and other serine proteases. Meth Enzymol 1972;25:655671.

27. Birk Y. The Bowman-Birk inhibitor. Int $J$ Peptide Protein Res 1985;25:113-131.

28. Seymour RA, Heasman PA. Tetracyclines in the management of periodontal diseases. J Clin Periodontol 1995;22:22-35. 
29. Sorsa T, Ding Y, Salo T, et al. Effects of tetracyclines on neutrophil, gingival and salivary collagenases. Ann NY Acad Sci 1994;732:112-131.

30. Doherty HS, Janusz MJ. Neutrophil proteases: Their physiological and pathological roles. In: Hellewell PG, Williams TJ, eds. Immunopharmacology of Neutrophils. London: Academic Press;1994:55-85.

31. Schaefer C, Mayer WK, Kruger W, Vaupel P. Microregional distributions of glucose, lactate, ATP and tissue $\mathrm{pH}$ in experimental tumours upon local hyperthermia and/or hyperglycaemia. J Cancer Res Clin Oncol 1993; 119:599-608.

32. Eggert FM, Drewell L, Bigelow JA, Speck, JE, Goldner $M$. The $\mathrm{pH}$ of gingival crevices and periodontal pockets in children, teenagers and adults. Arch Oral Biol 1991;36:233-238.

33. Messadi DV, Billings P, Shklar G, Kennedy AR. Inhibition of oral carcinogenesis by a protease inhibitor. J Natl Cancer Inst 1986;76:447-452.
Send reprint requests to: Dr. Jonathan M. Korostoff, Department of Microbiology, School of Dental Medicine, University of Pennsylvania, 4010 Locust St., Philadelphia, PA 19104. E-mail: jkorosto@pobox.upenn.edu

Accepted for publication July 12, 1999. 